\title{
Conceptual Merge of Ecohydrologic Watershed and Sponge City Techniques for Managed Sustainability and Strengthened Adaptive Capacity of Nile Delta Coastal Lakes, Egypt
}

\author{
Hala O. Abayazid
}

\begin{abstract}
Nile Delta coastal zone in Egypt has special socioeconomic and environmental importance, with internationally acknowledged wetland systems. However, sustainability and adaptive capacity are compromised with progressive developments. Coastal lakes serve basins with intermixed industrial, urbanized and agricultural activities, which require an integrative approach for strengthened adaptivity and sustainability management. This research study presents an innovative management plan that conceptually merges the EcoHydrology approach with the recently initiated Sponge City approach. Principles of both approaches are reviewed to select components that are applicable and practically approved in the Egyptian conditions and evolving changes in the study area of Edku coastal lake. With an analysis of regional activities as well as the use of remote sensing techniques, the study first establishes a base insight into the historic spatiotemporal alterations in Edku lake and its served basin. Then, the climate change impact is incorporated by water balance-related factors to consider potential flood and/or drought risks in the adaptation plan. The study presents preliminary results with System Dynamics (SD) simulations. Various scenarios have been examined using VensimPLE $\times 32$-based SD modeling. The scenarios covered alternate combinations of the proposed measures. Optimal 25-year managerial EcoHydro-Spongic Strategy is found with gradual application of Sponge City measures to prevent $30 \%$ of wastewater discharges, while Ecohydrology measures are projected to reduce $60 \%$ of pollutant loads into Edku lake from agricultural lands. Further $10 \%$ of pollution reduction is achievable with applied phyto-technology within the Lake.
\end{abstract}

Keywords: Coastal management, Edku Lake, Remote sensing, climate change, system dynamics, Nile Delta, Sponge City, Ecohydrology

\section{INTRODUCTION}

Coastal zone has a dynamic nature; with geophysical, ecological, and socioeconomic characteristics that are continually evolving and adapting. Yet excessive developments and climate changes disturb self-sustainability capacity.

Revised Manuscript Received on 30 July 2019.

* Correspondence Author

Dr. Hala Ossman Mokhtar Abayazid, Coastal Research Institute National Water Research Center Ministry of Water Resources and Irrigation, Egypt.

(C) The Authors. Published by Blue Eyes Intelligence Engineering and Sciences Publication (BEIESP). This is an open access article under the CC-BY-NC-ND license http://creativecommons.org/licenses/by-nc-nd/4.0/
The coastal region in North of Egypt has an advantageous environmental condition with intersecting benefits of fresh waters of the Nile branches, brackish water of coastal lakes, and extended Mediterranean Sea shoreline. While supporting developments, it hosts aquatic biota, recreational spots, and unlimited resources to benefit from.

Coastal lakes of the Nile Delta have been considered a nature reserve with environmentally rich system.

Furthermore, as located in the tail of extended drainage network, deltaic coastal lakes used to provide recovery media for municipal, agricultural and industrial drained wastewaters before reaching the Mediterranean Sea. Also, with climate change challenges in forms of changing precipitation patterns and Sea Level Rise (SLR), coastal lakes have been considered vital defense line to work as a buffer zone for potential SLR and flooding events. However, growing population, expanding urbanization, increasing development activities and altered hydrologic regime in the served basins have resulted in excessive loads that exceed lakes' assimilative capacity. At present, coastal lakes experience deteriorating biochemical state and disturbed flow dynamics within. As degrading system state would compromise the beneficial uses, a number of studies were triggered for assessment and restoration attempts (Siam and Ghobrial, 2000; Saad, 2003; Abayazid and AlShinnawy, 2012; El-Adawy et al., 2013; Ahmed and Kaiser, 2014; Abayazid, 2015; El-Kafrawy et al., 2015; Ismail et al., 2016; Hossen and Negm, 2017; Rostom et al., 2017). It has been estimated that $80 \%$ of coastal pollution comes from land-based sources (UNESCO-IHP, 2012). Conventionally, management measures recommend the reduction of polluting influents. Nevertheless, in application, that would slow down development processes. Therefore, there is an urgent need to address this dilemma using innovative Transdisciplinary management approach. This research study tackles coastal lake management with an integral viewpoint that merges source control with target measures on a basinwide scale. The study investigates non-conventional approaches; the ecohydrologic concept that proved successful [UNESCO-IHP, 2012], as well as the recently adopted Sponge City approach in selective cities in China. However, as managerial measures vary with local coastal conditions (Wolanski et al 2004), a representative study area of Edku deltaic lake has been selected to evaluate applicability in the Nile Delta coastal zone. 


\section{Conceptual Merge of Ecohydrologic Watershed and Sponge City Techniques for Managed Sustainability and Strengthened Adaptive Capacity of Nile Delta Coastal Lakes, Egypt}

The study proposes an adaptive strategy that interconnects biophysical features, anthropogenic constraints, and institutional functions. Based on the system components; hydro-climatic characteristics, development activities, lowlying hotspots, land-uses...etc., a framework for the proposed strategy is set to effectively manage sustainability and adaptive capacity of the coastal area under consideration. The study also presents the support that advanced earth observation and geo-informatic techniques can provide. Use of remote sensing technique has facilitated multi-temporal data collection, with reasonable accuracy and broad-scale coverage.

\section{MATERIAL \&METHODS}

\subsection{Study Area}

Lake Edku is located within the northwestern sector of the Nile Delta coastal zone, between longitudes $30^{\circ} 8^{\prime} \& 30^{\circ} 23^{\prime}$ E and latitude $31^{\circ} 10^{\prime} \& 31^{\circ} 18^{\prime} \mathrm{N}$ (Fig. 1). The lake is in AlBuhaira governorate, $19 \mathrm{~km}$ west of the Rosetta branch of the Nile River and about $30 \mathrm{~km}$ East of Alexandria city. Lake Edku is freely connected to the Mediterranean Sea with one opening "Boghaz Al-Maadia" that allows occasional tidal inflows.

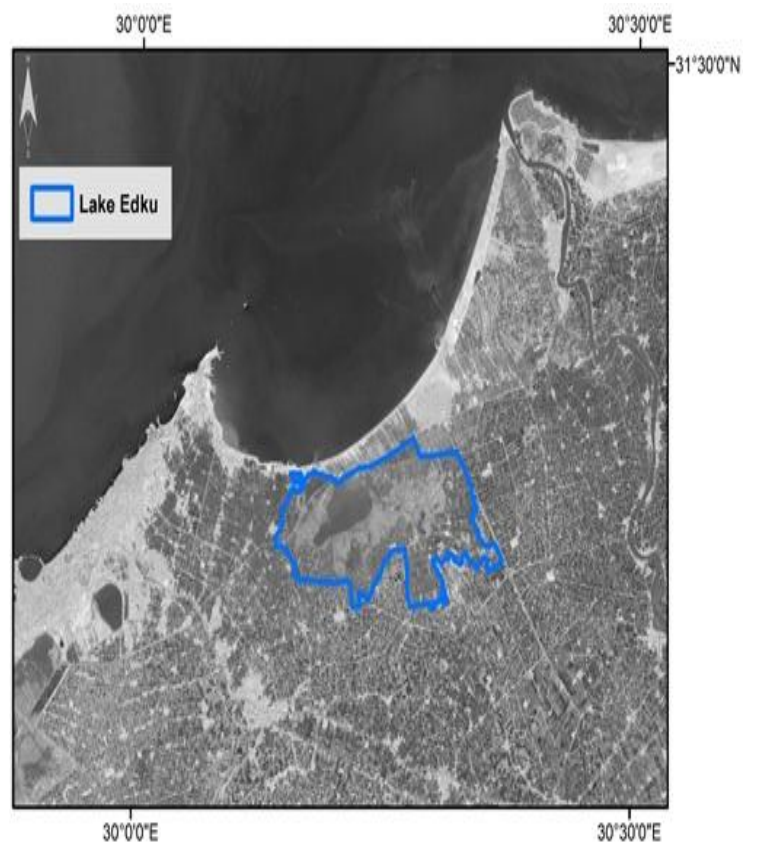

Figure 1: Study area - Lake Edku

Lake Edku has a history of steady shrinking in area, as shown in figure (2). It has diminished from $200 \mathrm{~km}^{2}$ to some $150 \mathrm{~km}^{2}$ in the 1950s, until reaching less than $75 \mathrm{~km}^{2}$ in present. It is estimated that reduction in lake area has occurred primarily through systematic drying, reclamation and expanding agricultural and commercial fish farming (Abayazid, 2015). Currently, three main features characterize the Edku lake system; aquaculture belt, vegetative patches, and the open water body connected to the Mediterranean Sea.

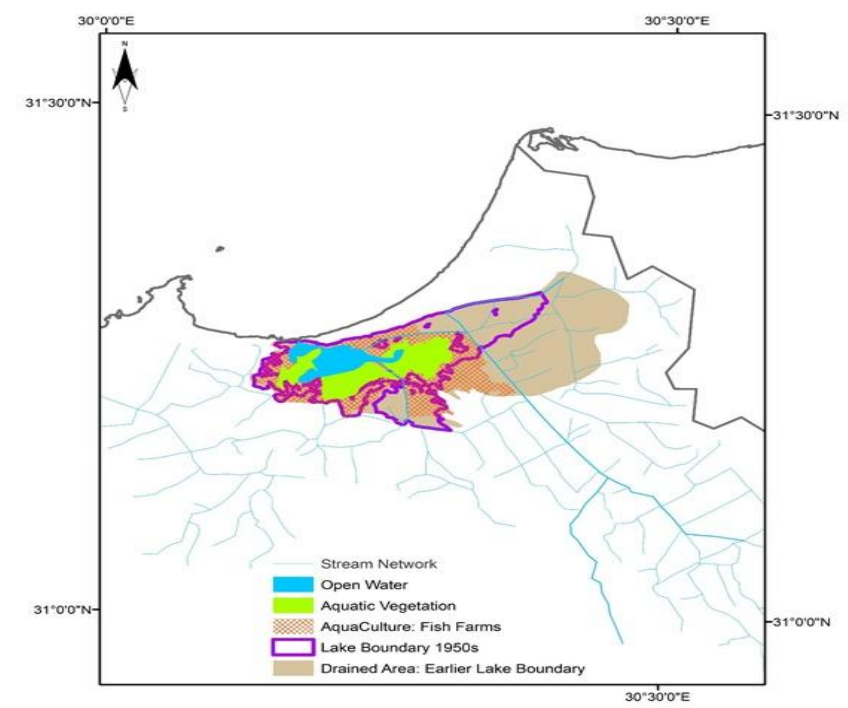

Figure 2: Historical changes in Lake Edku boundary and current zonation

The lake serves an actively populated basin, covering about $2000 \mathrm{~km}^{2}$, with interconnected agricultural drainage network. Drainage water discharging from Edku main drain, ElBoussili, Bearsik and Khairy drains have an average estimate of $60.3 \mathrm{~m}^{3} / \mathrm{sec}$ discharge rate (Azab, 2012]. Two major urban cities, Al-Buheira and Alexandria, and small towns with a growing population and expanding urban activities dispose wastewaters directly into stream networks and, eventually, into the Edku lake. In addition, discharges from industrial facilities (e.g. oils and textiles), Wastewater Treatment Plants (WWTPs), water reuse units, as well as aquacultural activities all end up into the lake's water. Disposed wastewaters are reported to have a high level of polluting impact especially nutrients; fertilizers and pesticides, and pathogens (Siam and Ghobrial, 2000) Lake Edku is considered a shallow eutrophic lake that rarely exceeding $1.5 \mathrm{~m}$ in depth, with similarity to a wetland system. The dominant aquatic plants in the lake are emergent reed Phragmites australis. However, floating water hyacinth "Eichhornia crassipes" and submerged plants

"Potamogeton pectinatus" and "Ceratophyllum demersum" have been intensified in recent decades to cover areas reaching about $50 \%$ of the lake open water, especially less saline sections away from the tidal influence (Okbah and ElGohary, 2002; Khalil et al., 2008; Azab, 2012; Hossen and Negm, 2017). Customarily, vegetation encourages active aquatic ecology in wetlands, and work as purifying media for drained wastewaters (Groffman, 1994). Yet, when nutrient levels exceed the receiving water assimilative capacity, undesirable excessive vegetation occurs. Another factor controls aquatic flora and fauna population distribution within the coastal lake is the salinity level (Teal, 2016). However, tidal saline inflows have a localized effect adjacent to the opening to the sea at Maadia due to excessive discharges of fresh water (Abdel Halim et al 2013). Accordingly, changes in nutrients and salinity levels disturb vegetative density and, hence, flow dynamic within the lake. Moreover, climate change-driven increase in temperature and heat waves, along with increasing nutrient-rich runoff, would increase the severity of vegetative blooms. 
That, in turn, would weaken the lake buffering capacity with predicted SLR and flooding events. Limited short-term success has been experienced with typical measures. Therefore, an integrated basin-wide approach for managed needed.

\subsection{Employing Remote Sensing Technique}

Imageries from Landsat ((TM, ETM+, and OLI) for path 178/row 038 were acquired from the U.S. Geological Survey's (USGS) freely accessible database in time steps from 1987 to 2017. Processing satellite imageries; raster calculations, thematic mapping, and result display were performed using the Integrated Land and Water Information System (ILWIS_3.7.2) model and Geographical Information Systems (GIS 10.1) software. Landsat imageries were used to detect evolving changes in Lake Edku and served basin. Spatiotemporal changes in land use/land cover within the lake's basin have been mapped using supervised image classification and Normalized Difference Built-up Index (NDBI), calculated as a function of Near Infrared (NIR) and Short Wave Infrared-1 (SW1) spectral bands, as stated in equation 1 (Zha et al., 2003).

$$
N D B I=\frac{R_{S W 1}-R_{N I R}}{R_{S W 1}+R_{N I R}}
$$

Eq. 1The Normalized Difference Vegetation Index (NDVI) has been used to reflect vegetative cover growth within the lake during three decades. As presented in equation 2, NDVI is calculated using Near Infrared (NIR) and Red (R) spectral bands.

$$
N D V I=\frac{R_{N I R}-R_{R}}{R_{N I R}+R_{R}}
$$

Imageries from the NASA Shuttle Radar Topographic Mission (SRTM) were used to feature topography and low lands within the study area. Accordingly, areas susceptible to high risk with potential flood events have been spotted.

\subsection{Water Resources-related Climate Change Components}

Projected changes in climate conditions were investigated in terms of main components of the water cycle in the study area under consideration. Water resources-related climate change on a coastal region is essentially linked to the change in rainfall regimes (frequency and intensity), temperature patterns and, hence, EvapoTranspiration (ET) rates. These principal indicators dictate potential extreme events with climate change; heat waves, droughts and/or flooding events. A wide range of General Circulation Models or Global Climate Models (GCMs) has been established with assumptions, scale and structure to reproduce climatological trends with greenhouse gas scenarios. Selected time series and predicted interannual variations for temperature and rainfall patterns were obtained from the geographically distributed system of HadGEM2 Model simulation results, with the moderate scenario of RCP4.5. Inter-comparison and analysis were also carried out, for selective time steps, with satellite-driven precipitation estimates of Tropical Rainfall and Measurement Mission (TRMM). The TRMM satellite system has been launched and operated by the United State lake sustainability and strengthened adaptive capacity is

Space Agency (NASA) and the Japanese Aerospace Exploration Agency (JAXA), with averaged monthly temporal resolution (Kummerow et al., 2000). It has been reported that TRMM estimates correlate reasonably well with ground-based measurements in low-altitude regions (Stampoulis \& Anagnostou, 2012; Hunink et al., 2014). Therefore, TRMM was selected for suitability to the nature of the region under consideration. The changing pattern of ET with time in the study area was also investigated. Monthly actual ET levels were retrieved from freely accessible data provided by The USGS Famine Early Warning System Network (FEWS NET) Data Portal. ET Data products are based on Moderate Resolution Imaging Spectroradiometer (MODIS) data acquired by the National Aeronautics and Space Administration's Earth Observing System (EOS). Information and images have been acquired from the website: (https://earlywarning.usgs.gov/fews), accessed in December 2017 and April 2018

\subsection{EcoHydrology Concept}

Hydrology, by definition, addresses water dynamic on the earth, and the changing physical and chemical properties with changing environment and activities. Derived from understanding the interrelation and continuous feedback between hydrology and ecosystem functions, the EcoHydrology concept has been developed by the International Hydrological Programme (IHP) of the UNESCO. Originally, ecohydrology was defined as an approach for sustainable water management at a watershed scale through employing the functional interface between hydrological and ecological processes (Rodriguez-Iturbe, 2000; Porporato et al., 2002; Zalewski, 2014; Timchenko, 2016; Zhou et al., 2016). Earlier, watershed-based management strategies have mostly been introduced with source control concept. Best Management Practices (BMPs) prevent pollution by taking proactive control measures; such as modifications to farming practices, manipulation with cropping patterns, using vegetative buffer strips, and applying improved maintenance and operational mechanisms (EPA, 2008). Also, Total Maximum Daily Loads (TMDLs) was introduced into action in the United States of America (USA) on the basis of specifying the maximum amount of pollutants that a waterbody can receive and still meet its beneficial uses. Maximum allowable loading into a waterbody is concluded by limiting waste loadings from both point sources (WLAs), nonpoint sources and natural background (LAs). EcoHydrology aims to enhance system assimilative capacity while avoiding drastic changes to practices already in place, by managing the biota and regulating hydrological processes throughout the served basin (Zalewski, 2000). The approach is based on adopting innovative management measures, along with low-cost technology, so that the affected ecosystem can be partially restored then, subsequently, natural recovery takes place gradually. With trans-disciplinary nature, EcoHydrology works as a process-oriented methodology; which considers measures such as Full-stop system for solute signatures at cultivated field level, upgraded land use practices, maintained stream network, and optimized cropping pattern versus unified cultivation. An essential component of the EcoHydrology concept is the use of ecosystem elements as management tools. 


\section{Conceptual Merge of Ecohydrologic Watershed and Sponge City Techniques for Managed Sustainability and Strengthened Adaptive Capacity of Nile Delta Coastal Lakes, Egypt}

Plants are employed as Environmentally Sound Technologies (ESTs) in addressing development's harmful issues. Macrophytes have been used to govern nutrient contents and consumption rate within a polluted aquatic ecosystem (Wolanski et al., 2004). The Phytotechnology is proved successful in restoring productive waterbody with improved water quality and optimized aquatic habitats. Introducing the right vegetative component can interplay the water biogeochemical cycle, strengthen the assimilate capacity and, hence, help restore a functional ecosystem (UNEP, 2003). While sharing the main EcoHydrology concept, the reviewed literature showed differences with watershed-specific nature. It was argued that there is no one commonly used EcoHydrology system or universally applicable formula. So, adjustments would be required to suit each case. Expanding urbanization, and hence increased impervious surfaces, in addition to climate change and changing rainfall pattern and intensity, created an extra difficulty with stormwater and drainage system.

Li (2012) presented a study that addresses such a problem using integrated EcoHydrology approach to BMPs and environmentally friendly urban design. However, the approach of Sponge city, recently initiated in China, add more innovative perception.

\subsection{Sponge City Approach}

In 2015, the Chinese government launched the Sponge city program as an environmentally friendly approach for alleviating extreme events of both floods and droughts in selective pilot applications. This two-facet program addresses the urbanization impact on the hydrologic cycle and reverses flash flooding into a solution to water scarcity in the dry season. Customarily, excessive rainfall water is rapidly directed out of the urbanized area to save infrastructure and active investments within. Sponge city concept is built on increasing urban system capacity to absorb, store and purify rainwater so that it can be readily released in drought time. However, Sponge city shares core concept with earlier practices that address interrelation between urbanization and water resources management, with a hydrologic-based viewpoint. Among those earlier practices that have been introduced in various scales are Low Impact Development (LID) in Canada and the USA (EPA, 2000), Water Sensitive Urban Design (WSUD) in Australia, and Sustainable Urban Drainage Systems (SUDS) in Europe (Shafique and Kim, 2015). These approaches overlap in some common grounds of urban spatial planning with water management consideration. To reverse inherited urban impact on the natural hydrologic water cycle, a shift is required from gray infrastructure, conventional impermeable systems that divert water off urbanized region through structural stormwater/sewage drainage network, to green infrastructure with environmentally sound measures. This practice, while alleviating the intensity of storm risk, helps in drought mitigation with reuse potential. Example measures are stated below:

(1) Permeable road surface and parking lot pavements Allowing porosity and higher permeability in pavement materials, instead of the customarily used waterresistant asphalt/concrete, would increase seepage into the subsoil, permit groundwater recharge and reduce flood risk (Xia et al., 2017).
(2) Rain garden/ Bioretention ponds Vegetation of low-lying areas with drought-tolerant plants would provide a spongy depression in flood events. Stormwater run-offs are to be redirected into those assigned green areas to reduce peak flow through infiltration. This practice proved to cause significant risk reduction (Shafique and Kim, 2015; Xia et al., 2017). Meanwhile, rain gardens provide public space for recreational use in no-rain seasons.

(3) Natural or constructed wetlands

Enhancing the use of wetlands offers environmentally sound sedimentary and bio-filtration processes.

(4) Urban water recycling

Greywater (household wastewater) and collected rainwater can be re-used for gardening, toilet flushing and washing at the building level.

(5) Green roofing or rooftop gardens

Vegetated roofs of urban buildings proved to be remarkably reducing the total urban runoff in excessive rainfall events (Xia et al., 2017). Richards et al. (2017) introduced an idea of shifting into productive vegetable garden, with adjusted soil properties, to gain popularity and encourage acceptance in wider scale within communities.

(6) Bio-swales system

Construction of shallow open channel system, filled with vegetation, is employed to redirect runoff and reduce floodwater velocity while allowing filtration and sedimentation processes.

(7) Public participation

The importance of raising public awareness, upgrading perception of water management issues and creating commitment are also emphasized (Campbell, 2016; Li et al., 2017; Norton et al., 2018).

This promising approach, however, faces operational and financial challenges. In application, integration of multiple subsystems is required (Msuya and Lalika, 2017; Xia et al., 2017). Strategy implementation requires inter-sectoral coordination at a basin-wide level while addressing incompatible, multi-source, data with different formats (Shao et al., 2016). Therefore, an effective communication plan across concerned parties; governmental and nongovernmental agencies, as well as regulated data exchange channels should be set. In addition, difficulties with financial support are likely encountered. Expanding urbanization, while initially driven by the growing population, is governed by economic interests that shrink green spaces to maximize high-priced buildable areas ( $\mathrm{Li}$ et al., 2017). Obstacles with funding resources triggered the Public-Private-Partnerships (PPP) concept.

Reviewed case studies provide standard measures and methodology in application. However, it was recommended to adjust the applied strategy as local specifications; resources and potential dictate.

\subsection{System Dynamic Simulation}

To get a representation of the lake system behavior and predicted responses with the proposed management measures, System Dynamic (SD) modeling was considered. This research study used the VensimPLE $\times 32$ software to investigate scenarios that reduce wastewater quantities and pollutant concentrations reaching the Edku lake, 
in addition to projected improvement in assimilative capacity with phytotechnology use. The scenarios investigated alternate combinations of management measures from both Ecohydrology and Sponge City approaches, as illustrated in figure (3). Proposed management scenarios were established so that the difference in contribution level from agricultural activities versus urban inputs is accounted for. Also, the look-up table technique was employed in order to reflect variable graded trends and time lag between measure application and concrete results. Planning scenarios were established with two timeframes; 50-year plan and 25-year plan in order to reflect potential constraints with technical and economic resources.

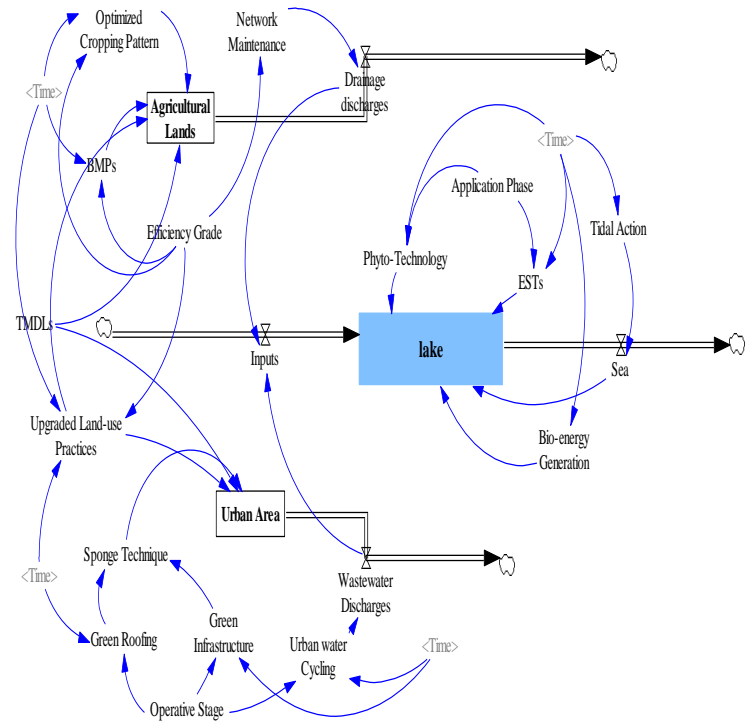

Figure 3: System dynamic structure with governing factors and managerial measures

III.

RESULTS

\section{1. $\quad$ Projected Changes in Climate Conditions}

Principal water cycle-related climate change components are rainfall and temperature that, in turn, affect evaporation and transpiration rates. Predicted changes for rainfall and temperature levels within the study area indicate a continuous increase in temperature (figures 4), and a declining trend of rainfall rates, with frequent extreme events (figure 5). Accordingly, the risk of potential extreme events; drought and flood, as well as heat waves, are projected.

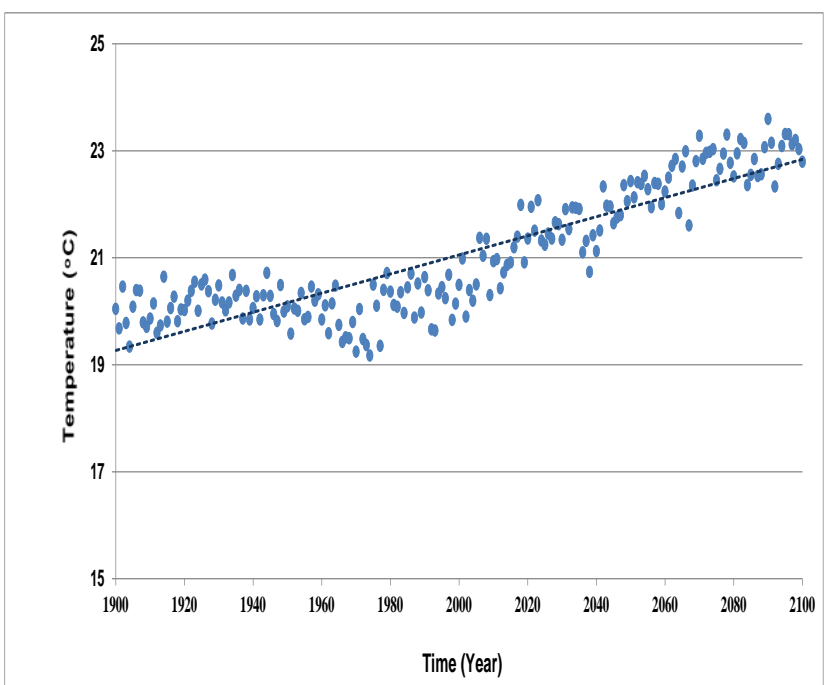

Figure 4: Changes in temperature pattern with climate change impact in the study area

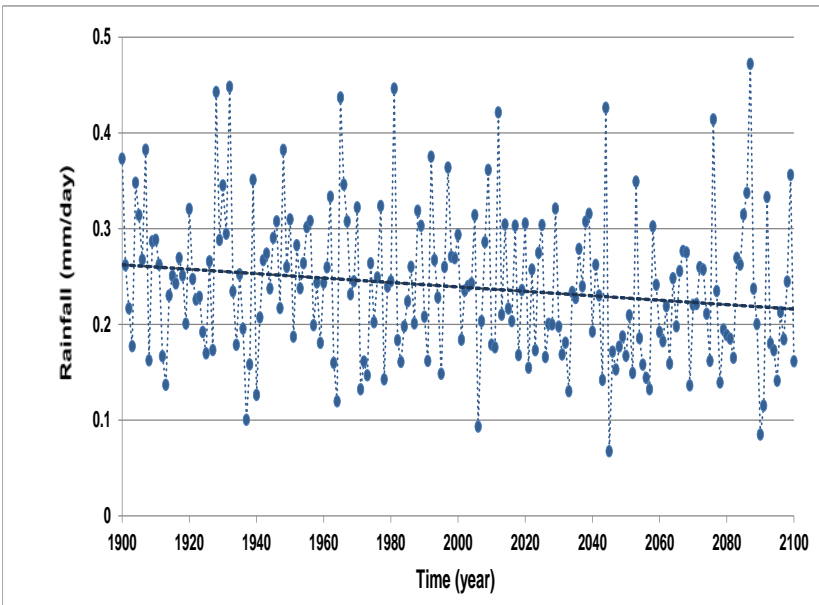

Figure 5: Changes in rainfall rate and intensity with climate change impact in the study area

\subsection{Changes in Edku Lake and Served Basin}

Following the changes of EvapoTranspiration rates during the last two decades, demonstrate stable overall range, with varying density distribution within the study area. Figure (6A-D) show examples of seasonal ET levels during the period from the year 2003 until the year 2017. Change in ET rate distribution is greatly affected by the change in land use/ land cover (figure 7); cultivated areas versus urban expansion. Changes in vegetative cover within Lake Edku, represented by Normalized Difference Vegetation Index (NDVI) levels (figure 8A-E), were also reflected on EvapoTranspiration rates. 
Conceptual Merge of Ecohydrologic Watershed and Sponge City Techniques for Managed Sustainability and Strengthened Adaptive Capacity of Nile Delta Coastal Lakes, Egypt
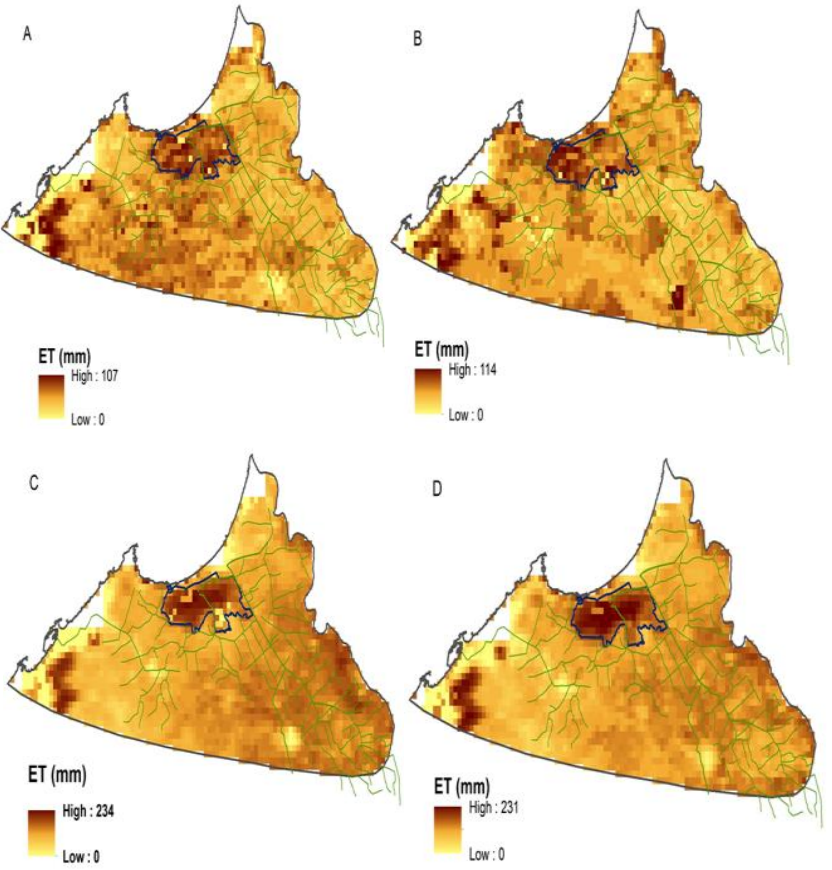

Figure 6 A-D: Selective Satellite-based

EvapoTranspiration in the study area during the period 2003 until 2017. A

(February, 2005), B (February, 2012), C (July, 2003), D (July, 2017)

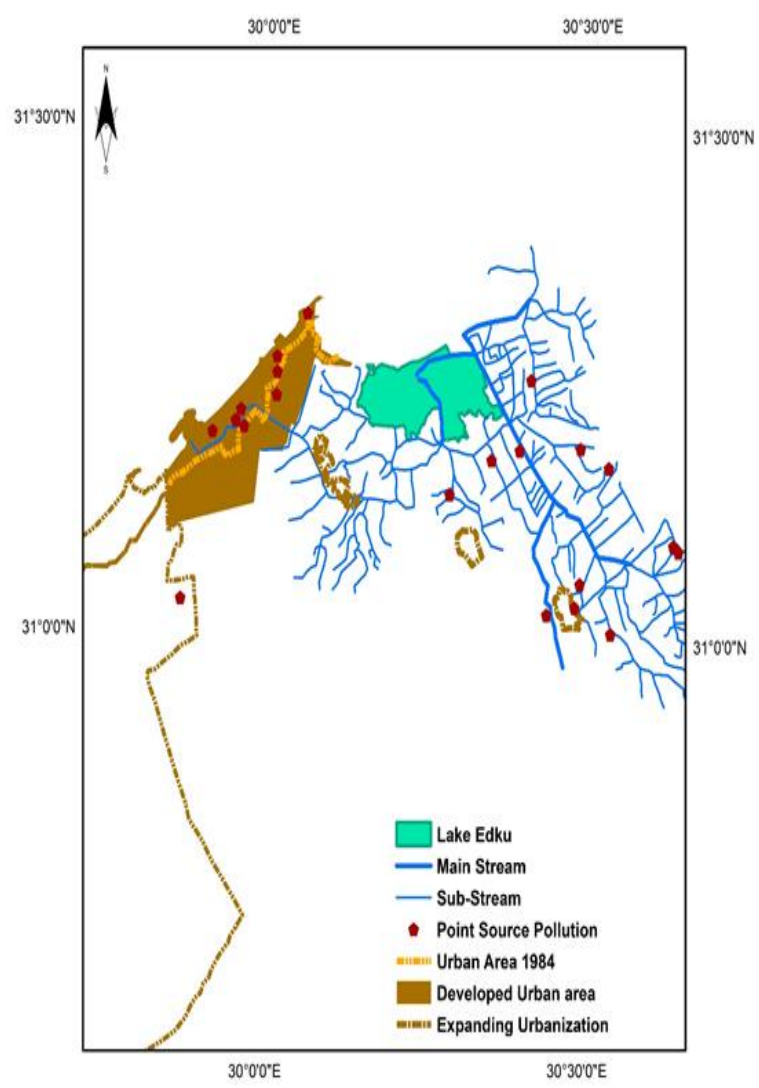

Figure 7: Basin-wide land use/ land cover and principal pollution sources

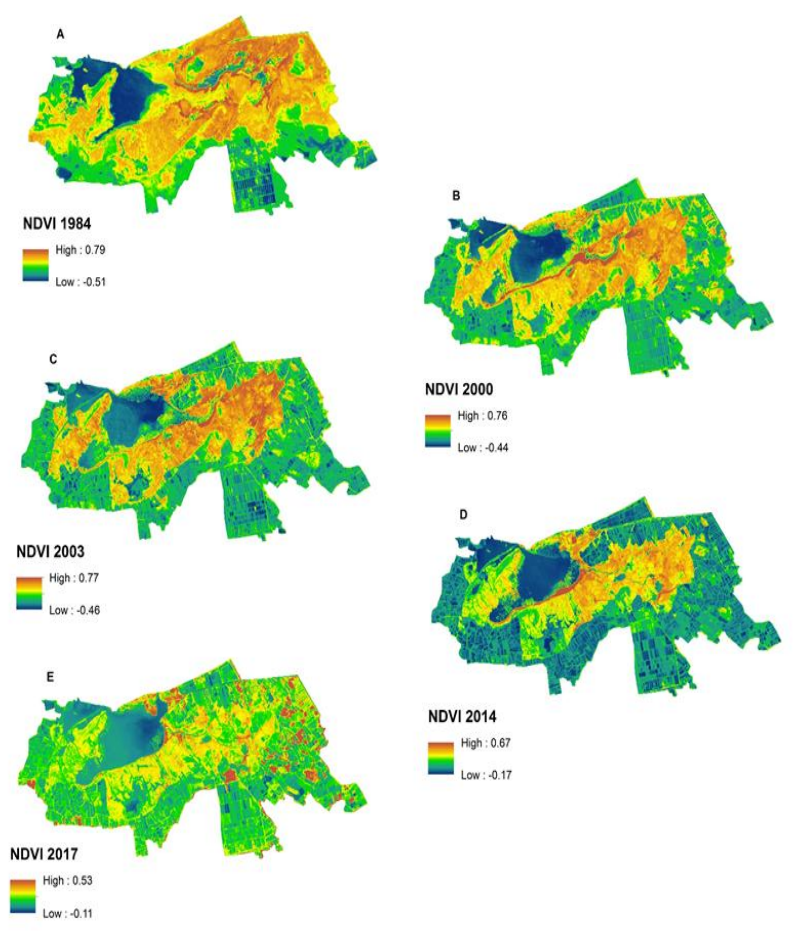

Figure 8A-E: Change in Normalized Difference Vegetation Index (NDVI) within Lake Edku from 1984 until 2017

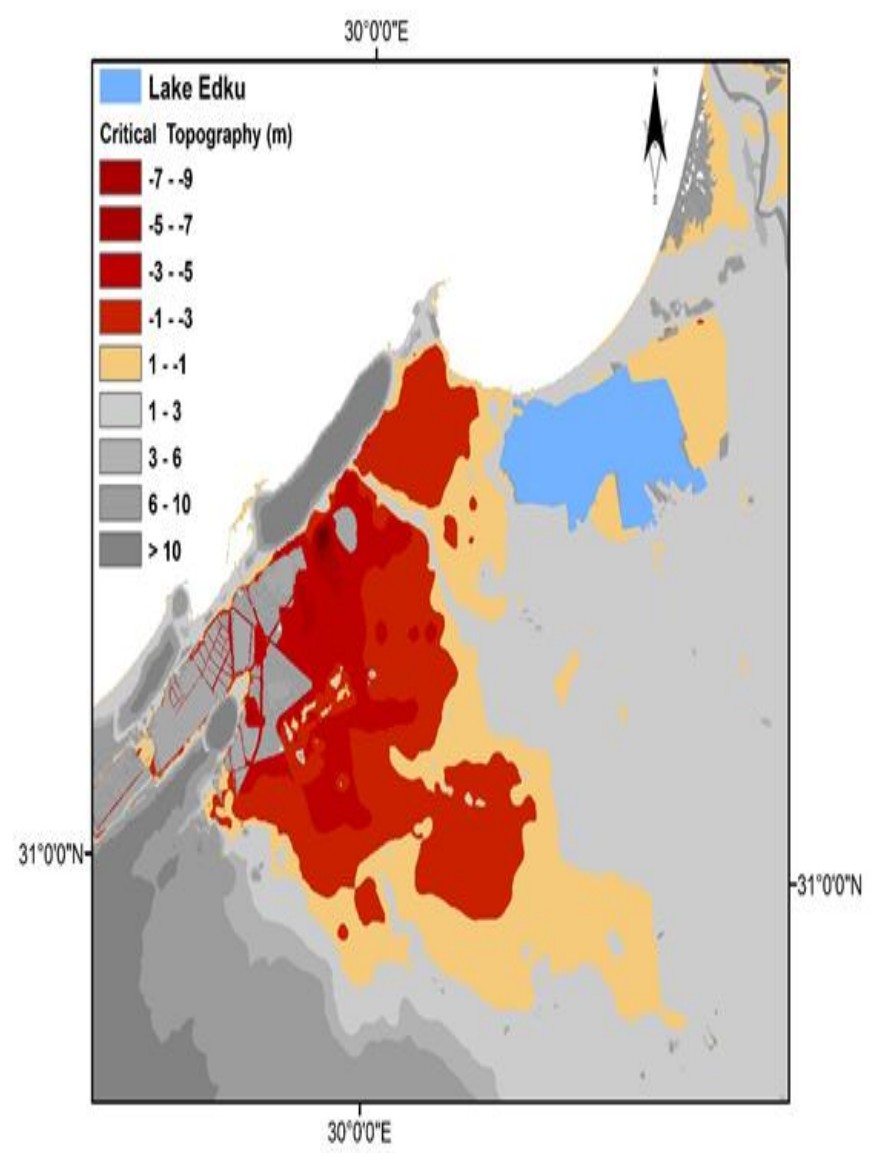

Figure 9: Topographic risk featuring in the lake-basin coastal zone: critical low-lying areas

\subsection{Topographic Feature}

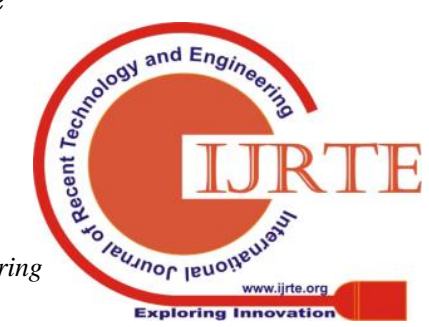


Spatial topographic feature (figure 9) is a key factor in risk analysis with climate change concerns. With potential sea level rise, storm surge and/or flood events, the low-lying areas are susceptible to inundation. Furthermore, elevated water table and salt-water intrusion into coastal groundwater would, in turn, threat infrastructure and investments in place. However, these areas can be employed as an adaptive measure by allocating selective spots to work as rain garden/ Bioretention ponds, and redirect excessive waters to flow towards that specified location.

\subsection{Proposed Management Strategy}

To reinforce Lake Edku potential sustainability and adaptive capacity under varying climatic conditions, the proposed strategy integrates applicable measures that fit the Nile Delta nature as well as the on-going developments. The management plan combines elements from both sourcecontrol and result-oriented principles. Meanwhile, the simultaneous application of top-down and bottom-up methodologies are considered (figure 10). The principal measures to be applied in urban areas, Edku lake, cultivated lands and stream network are presented below. However, the strategy comprises significant consideration to institutional and legislative arrangements, together with community involvement. Components of the proposed strategy are clustered with possible phasing in application.

\subsubsection{Urban areas}

- Shifting from gray to green infrastructure

- Green roofing in urban areas that have already been developed

- Introducing permeable pavements in new cities and expanding urbanization

- Allocating selective low-lying areas for bioretention and rain gardening. This measure will provide dual benefit by improving water quality while reducing peak flow destructive effects. Moreover, with concerns on SLR and saltwater intrusion into coastal groundwater, such proposed practices of rain gardens and permeable pavement application would have an additional benefit of holding back salinity interface.

\subsubsection{Lake Edku}

- Introducing governed phytoplankton populations "phytotechnology" to improve biological and physical state within the lake and control density of submerged weeds.

- Allocating defined section of the lake to work as wastewater treatment wetland; with phases of sedimentation, filtration and pollutant purification. Flow re-directing works would be needed to regulate input and output dynamics.

- Using excessive aquatic plants for bioenergy generation.

3.4.3. Cultivated lands and stream network

- Extend usage of Best Management Practices in cultivated fields

- Governed use of chemical fertilizers and pesticides

- Rehabilitation of stream network with improved smart monitoring and efficient maintenance.

- Enforcement of strict regulations for effluent treatment with optimized constraint and pollutant threshold levels:
- $\quad$ Operate supervised discharges from (WWTPs) and industrial facilities

- Apply Polluter Pays principle

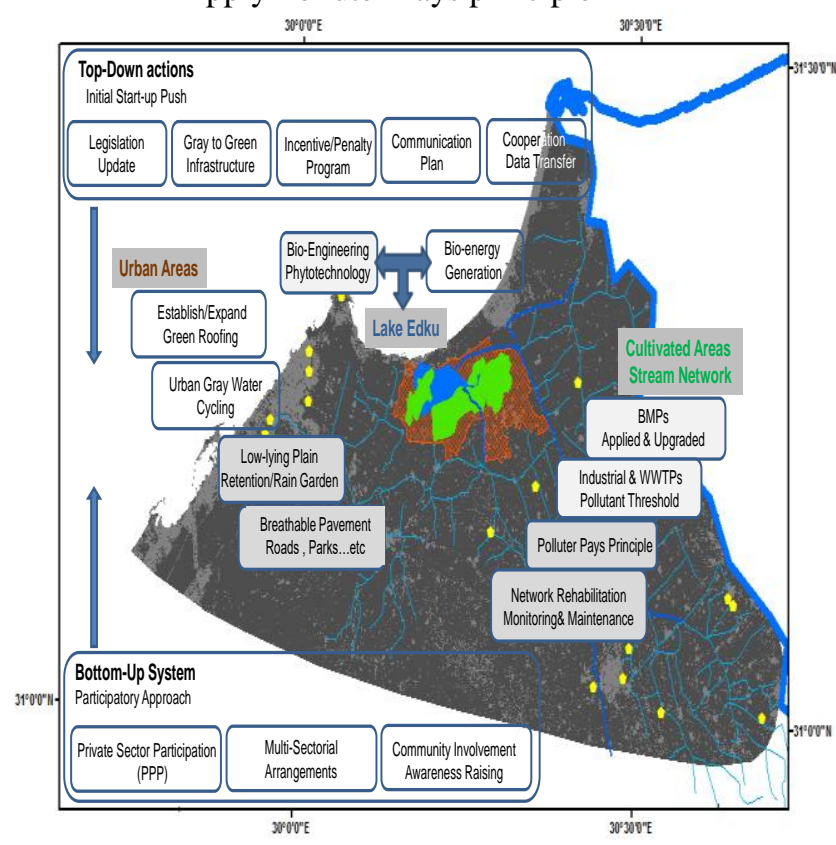

Figure 10: Conceptual framework for EcoHydroSpongic strategy

\subsection{Adaptive System Dynamics}

A wide range of management measures from both approaches was, primarily, considered. However, the final scenarios proposed in this study were selected with regard to applicability to regional conditions. The scenarios that address management approaches in a discrete manner required more than 50-year to achieve acceptable recovery of Lake Edku, example results are shown in figure (11). Alternatively, combined ecohydro-spongic measures accelerate the recovery of the lake. Simulations with reduced polluting effluents and improved water quality status in the lake are represented by recovered Water Quality Index (WQI). While current conditions in the lake have an averaged Water Quality Index of 0.4 (Okbah et al., 2017), the proposed strategy would restore WQI level to about 0.9 , as illustrated in figure (12). The results also reflect the expected prime slow response of the system during the first phase. Then the lake system shows a gradual positive response after 10 years.

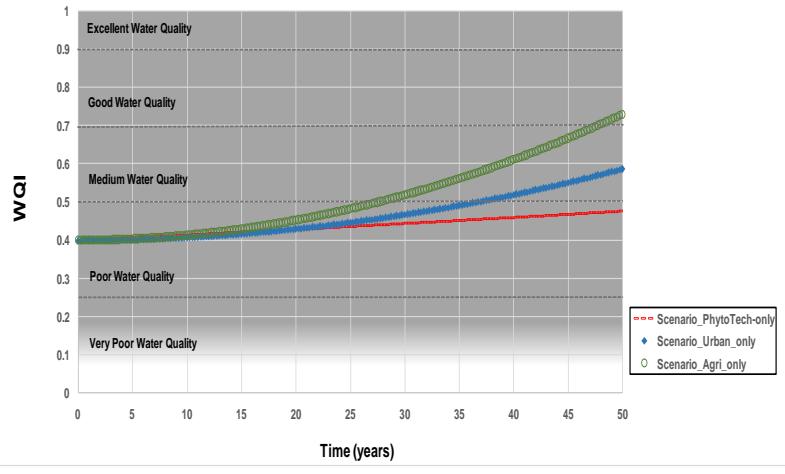

Figure11: Selective scenarios of improved water quality status for lake Edku with the 50-year management plans 


\section{Conceptual Merge of Ecohydrologic Watershed and Sponge City Techniques for Managed Sustainability and Strengthened Adaptive Capacity of Nile Delta Coastal Lakes, Egypt}

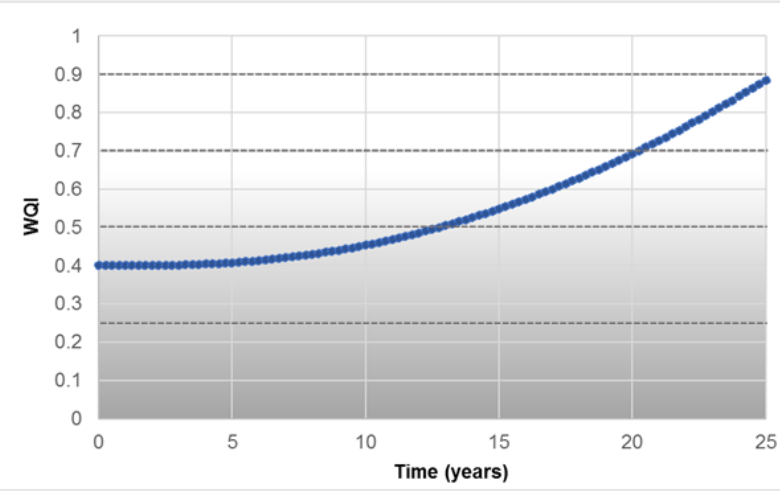

Figure 12: Projected lake restoration with 25-year integrated EcoHydro-Spongic Strategy

The optimal 25-year management plan is found with gradual application of Sponge City measures to prevent 30\% of wastewater discharges, while Ecohydrology measures are projected to reduce $60 \%$ of pollutant loads into the lake from agricultural lands. Further $10 \%$ of pollution reduction is achievable with applied phyto-technology within Edku Lake.

\section{DISCUSSION}

Deteriorating environmental conditions, in addition to concerns with climate change impact on the coastal zone, require operative action with innovative planning. This study followed aspects of the decadal changing environment, as well as the predicted hydro-climatic trends, in the study area. Consideration has been taken to factors, such as; evolving land use, aquatic ecology, and topohydrologic features. Consequently, vulnerability status dictated key measures to consider in setting a management strategy for improved sustainability and adaptability.

As it was proven that the severity of hazards is alleviated with improved social involvement, the strategy incorporates components that raise public awareness and promote positive participation of the local community.

Beside customarily faced change resistance, a number of challenges are expected in the financial, institutional and legislative fields. Challenge with financial support to deliver the required changes has been addressed in China by involving the private sector. Initial jump-start, however, has been provided by the governmental fund (top-down), and then the government dried up its contribution and encouraged private funding. Therefore, Public-PrivatePartnership (PPP) is expected to play an essential role in application. Challenges are also expected with required legislative and institutional amendments. Regulations governing jurisdictions and distributed responsibilities would require clear laws enforcement, with flexible changetracking policy, to back the proposed changes. Also, the interdisciplinary nature of the proposed basin-wide management strategy is expected to encounter challenges with the scattered, incompatible and cross-sectorial data sources. Accordingly, collaboration protocols for knowledge transfer and technical support are to be set in order to ease foreseen obstacles.
V.

\section{CONCLUSION \& RECOMMENDATION}

Deltaic coastal lakes of Egypt have multi-functional role to host rich ecosystem, alleviate pollution reaching the Mediterranean Sea, as well as help buffering potential climate change impact and Sea Level Rise. However, beneficial uses of these lakes are significantly compromised by progressive developments; increased pollution level and nutrient-rich influents into lakes. That, in turn, has intensely altered the aquatic environment and flow dynamics within the lakes. Management plans that suggest large-scale changes in development activities, infrastructures and investments in place are considered unfeasible in a developing country that already struggles with depleting resources. This research study introduces an integrative management strategy to strengthen both sustainability and adaptive capacity for a deltaic lake basin, Lake Edku, which serves an intermixed agri-urbanized basin. The proposed strategy sought a holistic viewpoint to consider crosssectorial; hydro-climatologic conditions as well as socioeconomic developments in the area of concern, using innovative reflects from both EcoHydrology and Sponge city approaches. While relying on the feedback mechanisms between hydrology and biota within the served basin, EcoHydrology employs low-cost technology to enhance assimilative capacity and restore ecosystem integrity. Meanwhile, the Sponge city approach offers measures that improve resilience to climate change risks in the urban environment, as well as allowing more effective use of water resources. The study employs remotely sensed data in the GIS environment for integrative analysis and change tracking, with effective spatiotemporal coverage. Further, System Dynamic modeling was used to represent lake system behavior and predicted responses with the proposed management measures. A wide range of management measures from both ecohydrology and sponge city approaches were, primarily, considered. However, the final scenarios proposed in this study were selected with regard to applicability in regional conditions. An optimal 25-year management plan is found with gradual application of Sponge City measures to prevent $30 \%$ of wastewater discharges, while Ecohydrology measures are projected to reduce $60 \%$ of pollutant loads into the lake from agricultural lands. Additional $10 \%$ of pollution reduction is achievable with applied phyto-technology within Edku Lake. The proposed EcoHydro-Spongic strategy for strengthened adaptive coastal lake recommends incorporating the social dimension of water resources management to ensure advocacy and continuous cooperation. It is also recommended to establish an effective communication plan and information sharing channels that are backed with a functional institutional mechanism and legislative amendments. Finally, allowing certain flexibility to regulations and law enforcement would ensure higher preparedness with uncertainty in climate predictions and environmental response.

\section{REFERENCES}

1. Abayazid, H., Al-Shinnawy, I., 2012. Coastal lake sustainability: threats and opportunities with climate change. J Mech Civil Eng Int Organ Sci Res (JMCE/IOSR) 1(5), 33-41 
2. Abayazid, H., 2015. Assessment of temporal and spatial alteration in coastal lakes-Egypt. In: Proceedings of the eighteenth International Water Technology Conference (IWTC 2015), Sharm El Sheikh, 12 14 Mar 2015, 598-608

3. Abdel Halim, A. M., Mahmoud, M. G.O., Guerguess, M. S., Tadros, H. R.Z., 2013. Major Constituents in Lake Edku Water, Egypt. Egyptian Journal of Aquatic Research (39), 13-20

4. Ahmed, S., Kaiser, M., 2014. Monitoring water pollution of lake mariout on the Mediterranean coast of Egypt. Int J Remote Sens Appl 4(1), 36-40. https://doi.org/10.14355/ijrsa.0401.03

5. Azab, A. M., 2012. Integrating GIS, Remote Sensing, and Mathematical Modelling for Surface Water Quality Management in Irrigated Watersheds. Phd Dissertation Delft University of Technology and the UNESCO-IHE Institute for Water Education. Delft, The Netherlands

6. Campbell, I.C., 2016. Integrated management in the Mekong River Basin. Ecohydrology and Hydrobiology 16 (4), 255-262

7. El-Adawy, A., Negm, A.M., Elzeir, M.A., Saavedra, O.C., ElShinnawy, I.A., Nadaoka, K., 2013. Modeling the hydrodynamics and salinity of el-Burullus Lake (Nile Delta, northern Egypt). J Clean Energy Technol 1(2),157-163

8. El-Kafrawy, S.B., Khalafallah, A., Omar, M, Khalil, M.H., Yehia, A., Allam, M., 2015. An integrated field and remote sensing approach for water quality mapping of Lake Burullus, Egypt. Int J Environ Sci Eng (IJESE) 6, 15-20

9. Groffman, P. M., 1994. Denitrification in Freshwater Wetlands. Wetland Biogeochemistry Institute, Louisiana State University, Baton Rouge, Cument Topics in WetlandBiogeochemistry 1, 63-78

10. Hossen, H. Negm, A., 2017. Sustainability of Water Bodies of Edku Lake, Northwest of Nile Delta, Egypt: RS/GIS Approach. Procedia Engineering 181, 404 - 411

11. Hunink, J.E., Immerzeel, W.W., Droogers, P., 2014. A Highresolution Precipitation 2-step mapping Procedure (HiP2P) Development and application to a tropical mountainous area. Remote Sensing of Environment 140, 179-188

12. Ismail, M., Yehia, H., Morsy, I., 2016. Environmental Study for Rashid and Idko Districts, El Behira Governorate, Egypt by using Remote Sensing and Geographic Information System techniques Land and Water Resources Assessment for Sustainable Agricultural Development. Alex. J. Agric. Sci. 61(3), 315-332

13. Khalil, M., Shakir, S., Saad, A., El Shabrawy, G., Hassan, M., 2008. Physio-Chemical Environment of Lake Edku, Egypt. J. Aquat. Biol. \& Fish. ISSN 1110-1131. 12(2), 119-132

14. Kummerow, C., Simpson, J., Thiele, O., Barnes, J., Chang, A. T. C. Stocker, E., Adler, R. F., Hou, A., 2000. The status of the Tropical Rainfall Measuring Mission (TRMM) after two years in orbit. J. Appl. Meteorol. 39, 1965-1982

15. Li, C., 2012. Ecohydrology and Good Urban Design for Urban Storm Water-Logging in Beijing, China. Ecohydrology and Hydrobiology 12(4):287-300 · DOI: 10.2478/V10104-012-0029-8

16. Li, H., Ding, L., Ren, M., Li, C., Wang, H., 2017. Sponge City Construction in China: A Survey of the Challenges and Opportunities. Water (9), Pp 594; Doi:10.3390/W9090594

17. Msuya, T. S., Lalika, M. C. S., 2017. Linking Ecohydrology and Integrated Water Resources Management: Institutional challenges for water management in the Pangani Basin, Tanzania. Ecohydrology and Hydrobiology, Pp 18, https://doi.org/10.1016/j.ecohyd.2017.10.004

18. Norton, R. K. , David, N. P., Buckman, S., Koman, P. D., 2018 Overlooking the coast: Limited local planning for coastal area management along Michigan's Great Lakes. land use policy (71), 183-203

19. Okbah, M. A., El-Gohary, S., 2002. Physical and Chemical Characteristics of Lake Edku Water, Egypt. Mediterranean Marine Science (3/2), 27-39

20. Okbah, M., Abd El-Halim, A., Abu El-Regal, M., Nassar, M., 2017. Water quality assessment of Lake Edku using physicochemical and nutrients salts, Egypt. Chemistry research journal 2 (4), 104-117.

21. Porporato, A., D’Odorico, P., Laio, F., Ridolfi, L., Rodriguez-Iturbe, I., 2002. Ecohydrology of water-controlled ecosystems. Adv. Water Resour. 25 (8), 1335-1348.

22. Richards, P. J., Williams, N. S. G., Fletcher, T. D., Farrell, C., 2017. Can raingardens produce food and retain stormwater? Effects of substrates and stormwater application method on plant water use, stormwater retention and yield. Ecological Engineering (100), 165 174

23. Rodriguez-Iturbe, I., 2000. Ecohydrology: a hydrologic perspective of climate-soil-vegetation dynamics. Water Resour. Res. 36 (1), 3-9

24. Rostom, N.G., Shalaby, A.A., Issa, Y.M., Afifi, A.A., 2017 Evaluation of Mariut Lake water quality using hyperspectral remote sensing and laboratory works. Egypt J Remote Sens Space Sci (20 Supp11), S39-S48

25. Saad, M. A. H., 2003. Impact of Diffuse Pollution on the SocioEconomic Development Opportunities in the Coastal Nile Delta Lakes. Diffuse Pollution Conference - Dublin, 6.81-6.85

26. Shafique, M., Kim, R., 2015. Low Impact Development Practices: A Review of Current Research and Recommendations for Future Directions. Ecol Chem Eng S. 22(4), 543-563, Doi: 10.1515/Eces2015-0032

27. Shao, W., Zhang, H., Liu, J., Yang, G., Chen, X., Yang, Z., Huang, H., 2016. Data integration and its application in the sponge city construction of China. Procedia Engineering 154, 779 - 786

28. Siam, E., Ghobrial, M., 2000. Pollution influence on bacterial abundance and chlorophyll-a concentration: case study at Idku Lagoon, Egypt. Scientia Marina SCI. MAR., 64 (1), 1-8

29. Stampoulis, D., Anagnostou, E. N., 2012. Evaluation of global satellite rainfall products over Continental Europe. Journal of Hydrometeorology, 13(2), 588-603. http://dx.doi.org/10.1175/JHMD-11-086.1.

30. Teal, J., 2016. Succession in coastal wetlands . Springer Science+Business Media Dordrecht, C.M. Finlayson et al. (eds.), The Wetland Book, DOI 10.1007/978-94-007-6172-8_2-3

31. Timchenko, V., 2016. Ecological hydrology (ecohydrology) as a part of the aquatic ecology. Ecohydrology and Hydrobiology 16(2), 117124

32. United Nations Environment Program (UNEP), 2003 Phytotechnologies. A technical approach in environmental management. UNEP Division of Technology, Industry and Economics. Freshwater Management Series No.7

33. United Nations Educational, Scientific and Cultural Organization (UNESCO), International Hydrological Programme Eighth Phase (IHP-Viii) (2014-2021), Water Security: Responses to Local, Regional, and Global Challenges -Strategic Plan, $20^{\text {th }}$ Session of the Intergovernmental Council Paris June 4-7, 2012

34. United States' Environmental Protection Agency (EPA). 2000, Low Impact Development (LID) A literature review. 841-B-00-005

35. United States' Environmental Protection Agency (EPA). Office of Wetlands, Oceans, and Watersheds, 2008. Handbook for developing watershed TMDLs, Pp168

36. Wolanski, E., Boorman, L.A., Chicharo, L., Langlois-Saliou, E., Lara, R., Plater, A.J., Uncles, R.J., Zalewski, M., 2004. Ecohydrology as a new tool for sustainable management of estuaries and coastal waters, Wetlands Ecology and Management 12, 235-276

37. Xia, J., Zhang, Y., Xiong, L. H., He, S., Wang, L. F., Yu, Z. B., 2017. Opportunities and challenges of the sponge city construction related to urban water issues in China. Science China Earth Sciences 60, 652-658, Doi: 10.1007/S11430-016-0111-8

38. Zalewski, M., 2000. Ecohydrology-The scientific background to use ecosystem properties as management tools toward sustainability of water resources. Ecol. Engng 16, 1-8

39. Zalewski, M., 2014. Ecohydrology and hydrologic engineering: regulation of hydrology-biota interactions for sustainability. J Hydrol. $\quad$ Eng., http://dx.doi.org/10.1061/(ASCE)HE.19435584.0000999

40. Zha, Y., Gao, J., Ni, S., 2003. Use of normalized difference built-up index in automatically mapping urban areas from TM imagery. Int. J. Remote Sens. 24 (3), 583-594

41. Zhou, D., Zhang, H., Liu, C., 2016. Wetland ecohydrology and its challenges. Ecohydrology and Hydrobiology 16 (1), 26-32 